\title{
Controlling factors of hazardous debris flow in Taiwan
}

\author{
Hongey Chen* \\ Department of Geosciences, National Taiwan University, No. 1, Section 4, Roosevelt Road, Taipei, Taiwan
}

Available online 28 October 2005

\begin{abstract}
Three unanticipated large-scale debris flows occurred in various rock type areas during typhoons that passed through Taiwan. The present study identifies possible hazard factors and the triggering mechanism. Several investigative methods relevant to these ends were selected, including aerial photo analysis, discontinuity patterns and geomaterial characteristics. In affected gullies, conjoined discontinuities protruded to the point of material slumping and producing large volumes of debris. In heavy rainfall, such debris tends to flow downward into the gullies. Discontinuity distribution produces geometric models of potential failure in plane, wedge and toppling forms. These slumping materials had been introduced and had accumulated along the gullies under study. Rapidly increasing water pressure caused by heavy precipitation provided a powerful force that triggered the debris flow movement. Large masses of slurry changed into an effective cutting force to erode the sidewalls, resulting in more masses of slumping materials converging in the gully and quickly funnelling down into the lower gullies.
\end{abstract}

(C) 2005 Elsevier Ltd and INQUA. All rights reserved.

\section{Introduction}

Three large-scale debris flows occurred in various rock type areas during typhoons that passed through Taiwan from 1990 to 2000 without forewarning (Fig. 1). On 23 June 1990, Typhoon Ofelia brought torrential rains at the rate of $906 \mathrm{~mm} /$ day to the Tungmen area of eastern Taiwan. Typhoon Herb dumped heavy precipitation at the rate of $1748 \mathrm{~mm} /$ day in the Hoser area of central Taiwan at the end of July 1996. And Typhoon Xangsane was responsible for $106 \mathrm{~mm} / \mathrm{h}$ rainfall in the Chonho area of northern Taiwan on 31 October 2000. These typhoon rains wreaked a terrible cost in human life and property. There were over 50 casualties and property losses totalled over US\$800 million.

Tungmen is located to the west of Hualien city (Fig. 2), a metamorphic region in eastern Taiwan. The elevation of the Tungmen area ranges from 130 to $570 \mathrm{~m}$, with gully slopes varying from $20^{\circ}$ to $55^{\circ}$. Hoser is located in the southern part of Nantou County, a sedimentary region in central Taiwan. The elevation of the Hoser area ranges from 820 to $1150 \mathrm{~m}$, with gully slope grades from $15^{\circ}$ to $45^{\circ}$. Chonho is located in the southeast part of Taipei city,

\footnotetext{
${ }^{*}$ Tel.: + 8862 33662946; fax: + 886223636095

E-mail address: hchen@ntu.edu.tw.
}

in a volcanic region of northern Taiwan. The elevation of the Chonho area ranges from 50 to $425 \mathrm{~m}$, with gully slope grades ranging from $5^{\circ}$ to $40^{\circ}$.

Various methods, including analysis of aerial photographs, discontinuity distribution, and geomaterial characteristics were utilized for conducting this study. Aerial photograph analysis was used to delineate topographical changes in the gully beds and on the mountain slopes before and after the debris flow over a 10-20 year period. Discontinuity distribution was investigated to ascertain the geometrical models of rock failure types of the gully slopes. Through the experimental testing, the relative shear strength of the geomaterial characteristics was obtained in saturated and unsaturated conditions. Then, the parameters of shear strength were applied to the analysis of slope stability in the study areas. The analyses helped this study to identify and obtain a better understanding of the triggering mechanism of the hazardous landslide and debris flow than the study could have obtained by any single investigative approach (Baldwin II et al., 1987).

\section{Aerial photography}

Aerial photographs chosen from different periods were examined to compare the morphological alterations and offer an integrated view of the study areas. In this way, the 


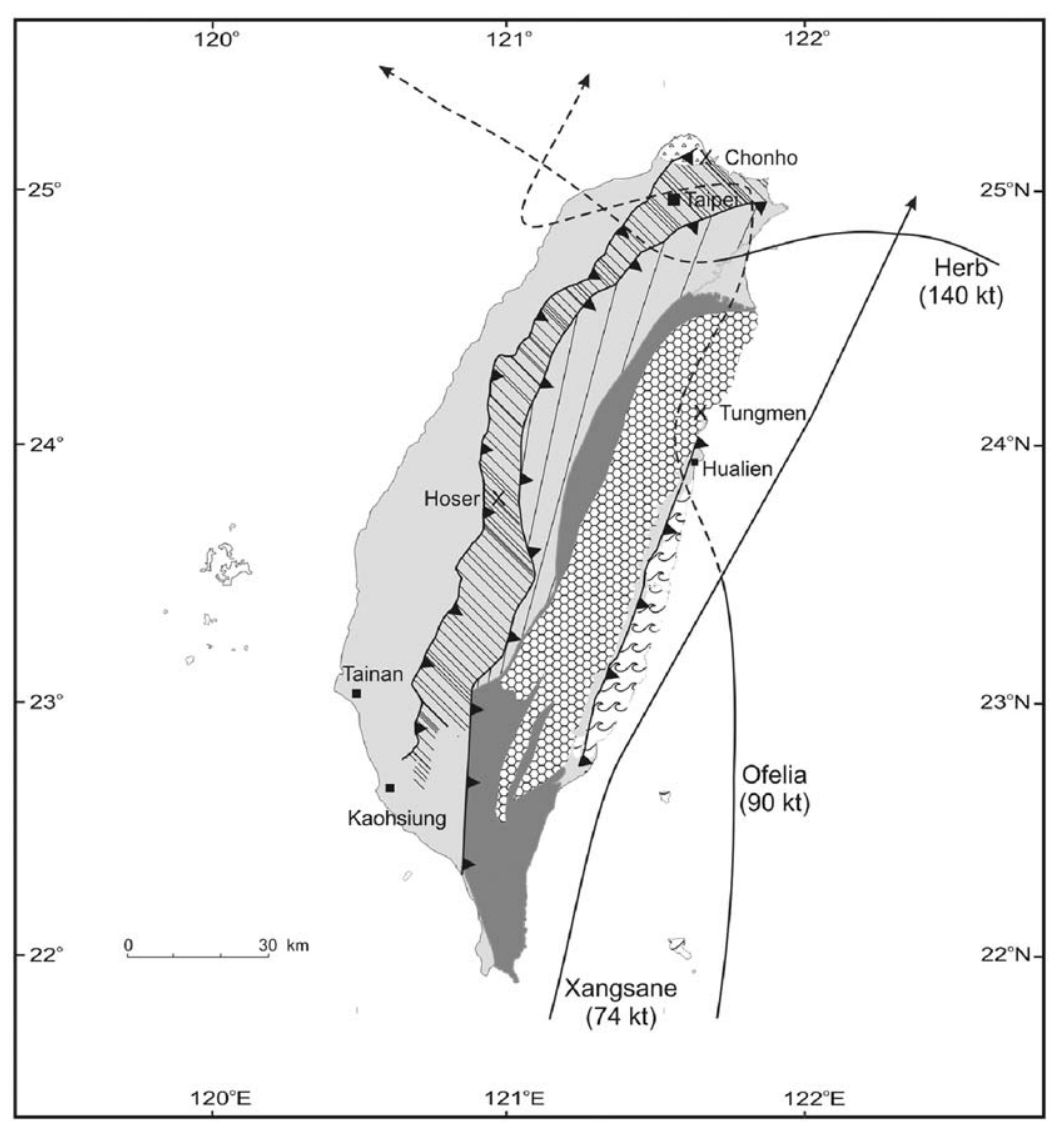

$\begin{array}{lll}\square & \text { Miocene slate } & \text { costal plain } \\ \text { Paleogene slate } & \text { Neogene melange } \\ \text { Miocene sedimentary sequence } & \text { thrust fault belt } & (74 \mathrm{kt}) \text { Maximum wind velocity }\end{array}$

Fig. 1. Schematic map showing the tracks of three different typhoons and the lithologic distribution of Taiwan.

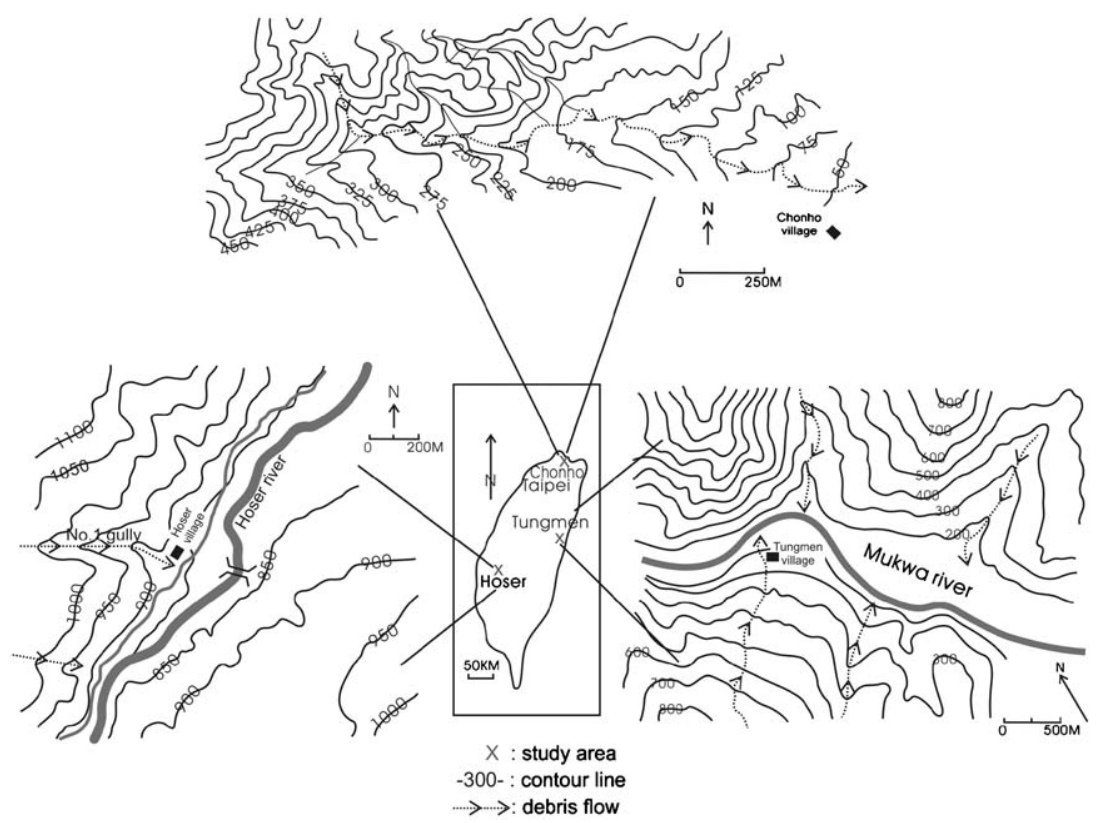

Fig. 2. Location of the study areas. 

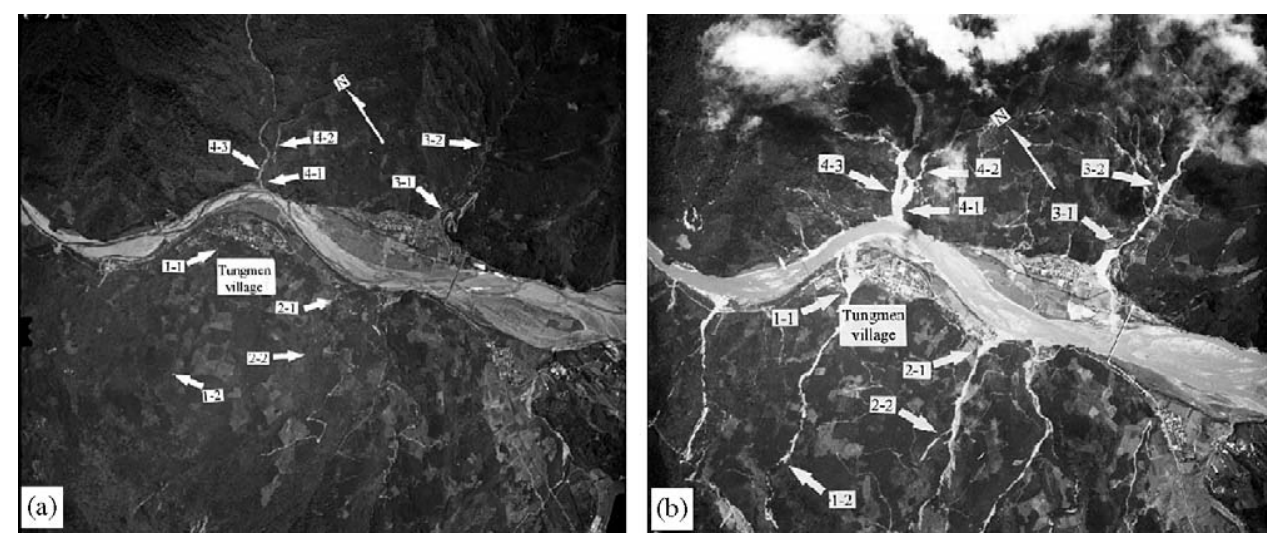

Fig. 3. Annotated aerial photographs of the Tungmen area taken before the disaster in 1980 (a) and after the disaster in 1990 (b), showing the last 10 years of morphologic changes.
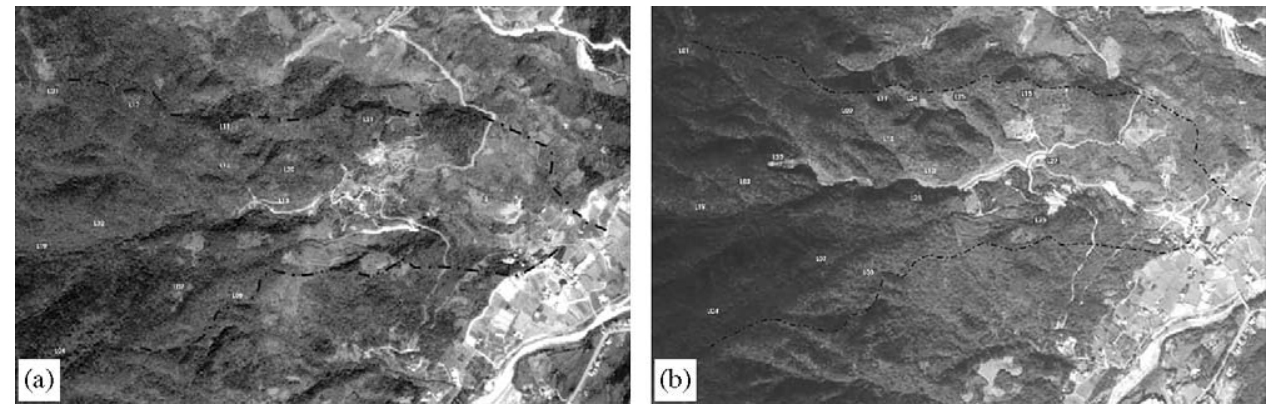

Fig. 4. The aerial photographs of the Chonho area taken before the disaster in 1994 (a) and after the disaster in 2001 (b) showing topographic features.

existing slope failures and the depositions in the gully channels could also be quickly traced (Rib and Liang, 1978; VanDine, 1985). For example, photographs taken in the Tungmen area in 1980, 1985, and 1990 were examined in order to contrast the successive alterations of morphology (Fig. 3). Photographs taken in the Hoser area in 1980, 1985, 1988, 1993 and 1996, thus covering a 16-year period, were similarly compared. Finally, photographs taken in the Chonho area in 1979, 1986, 1994 and 2000, covering a 20year period, were also examined for comparison (Fig. 4). The symbols $1-1,1-2,1-3$ or L02, L13, L22, etc. on the aerial photographs were used to indicate the specific changes in topography that occurred during the different periods in the respective study areas.

Aerial photographs from different times show that gully shapes and widths changed little before the typhoon occurrence (Chen, 2000). They reveal that the typhoons caused the higher slopes of the watersheds to experience a large number of failures, particularly on the sidewalls of the gullies. In short, the aerial photograph interpretations provided a way to trace the topographic changes in the catchments before and after debris flow over one or two decades of time.

\section{Morphologic changes}

Debris flow components are found in three different areas: the source area, the flow area, and the deposition area (Shlemon et al., 1987; Takahashi, 1991). On-site investigation showed whether the geomaterial sources were freshly broken in-situ materials or other older materials. Most of the gully wall had been eroded from a "V" shape into a "U" shape. This indicated that the debris flow forces were very powerful. The observed morphologic changes also indicated that the gully had been undercut and denuded downward to both lateral sides of the gully, changing the cross section from a "V" to a "U" (Table 1). Consequently, estimation of the respective morphologic changes of these three study areas did help in the interpretation of the debris flow.

To identify morphologic changes, the profile analyses from the source area, flow area and deposition area of the gully were used to ascertain the volume changes before and after the collapse at $25 \mathrm{~m}$ intervals. In analyzing the Tungmen area, 57 profiles were chosen from the source area, elevation $570 \mathrm{~m}$, to the deposition area, elevation $200 \mathrm{~m}$, and the changes in topography before and after debris flow was also compared (Table 2). The volume of deposited material from the source area in the Tungmen area after the debris flow was around $105,075 \mathrm{~m}^{3}$. A total of $31,387 \mathrm{~m}^{3}$ was deposited in the flow area of the gully, with another $73,687 \mathrm{~m}^{3}$ remaining at the deposition area, located between the mouth of the gully and the Mukwa river.

In the Hoser area, 34 profiles were chosen to analyze topographic differences from the source area, elevation 
Table 1

The comparison of morphologic changes in the gully profiles before and after debris flow of the study areas

\begin{tabular}{|c|c|c|c|c|c|c|}
\hline Study areas & Parts & Elevation (m) & Morphological changes & Slope grade & Gully shape & Remark \\
\hline \multirow[t]{3}{*}{ Tungmen } & Source area & $570-475$ & $\begin{array}{l}\text { The gully was undercut on both } \\
\text { lateral sidewalls after debris } \\
\text { flow }\end{array}$ & $19^{\circ}$ & $\mathrm{V}$ shape before flow & Erosion $5 \mathrm{~m}$ \\
\hline & Flow area & $475-203$ & $\begin{array}{l}\text { The gully was undercut with } \\
\text { erosion on lateral sidewalls and } \\
\text { some small lobes were left } \\
\text { deposited on the gully side. }\end{array}$ & $20^{\circ}$ & $\begin{array}{l}\text { U shape after flow } \\
\text { U shape before flow }\end{array}$ & Erosion $3.5 \mathrm{~m}$ \\
\hline & Deposited area & $203-165$ & $\begin{array}{l}\text { Major feature was massive } \\
\text { deposition with minor areas of } \\
\text { erosion. }\end{array}$ & $9^{\circ}$ & $\begin{array}{l}\text { U shape after flow } \\
\text { Alluvium }\end{array}$ & $\begin{array}{l}\text { Deposition } 2 \mathrm{~m} \\
\text { Deposition } \\
1.5 \mathrm{~m}\end{array}$ \\
\hline \multirow[t]{3}{*}{ Hoser } & Source area & $1023-970$ & $\begin{array}{l}\text { The west sidewall of gully } \\
\text { collapsed seriously. }\end{array}$ & $16^{\circ}$ & V shape before hazard & Erosion $6 \mathrm{~m}$ \\
\hline & Flow area & $970-868$ & $\begin{array}{l}\text { The eroded area is much bigger } \\
\text { than source area. Both sidewalls } \\
\text { of the gully have a lot of } \\
\text { erosion. }\end{array}$ & $18^{\circ}$ & $\begin{array}{l}\text { U shape after hazard } \\
\mathrm{V} \text { shape before hazard }\end{array}$ & Erosion $4 \mathrm{~m}$ \\
\hline & Deposited area & $868-820$ & $\begin{array}{l}\text { A big deposited area covered on } \\
\text { the old delta fan after debris } \\
\text { flow. }\end{array}$ & $9^{\circ}$ & $\begin{array}{l}\text { U shape after hazard } \\
\text { Alluvium }\end{array}$ & $\begin{array}{l}\text { Deposition } \\
11 \mathrm{~m}\end{array}$ \\
\hline \multirow[t]{3}{*}{ Chonho } & Source area & $425-300$ & $\begin{array}{l}\text { A big landslide occurred in the } \\
\text { source area. The gully was } \\
\text { undercut on both sidewalls after } \\
\text { flow. }\end{array}$ & $40^{\circ}$ & V shape & Erosion $12 \mathrm{~m}$ \\
\hline & Flow area & $300-110$ & $\begin{array}{l}\text { The eroded area is much bigger } \\
\text { than the source area. Both } \\
\text { sidewalls show marked erosion. } \\
\text { Large deposits covered the } \\
\text { lower parts of the main gully. }\end{array}$ & $15^{\circ}$ & $\mathrm{V}$ shape before hazard & Erosion $4 \mathrm{~m}$ \\
\hline & Deposited area & $110-50$ & $\begin{array}{l}\text { A substantial amount of } \\
\text { deposited material covers } \\
\text { around } 100 \mathrm{~m} .\end{array}$ & $5^{\circ}$ & $\begin{array}{l}\text { U shape after hazard } \\
\text { Alluvium }\end{array}$ & $\begin{array}{l}\text { Deposition } 5 \mathrm{~m} \\
\text { Deposition } 5 \mathrm{~m}\end{array}$ \\
\hline
\end{tabular}

Table 2

The volume of accumulated material from the different parts of the debris flow gully in the three study areas

\begin{tabular}{lllr}
\hline Study areas & Section & & \\
\cline { 2 - 4 } & $\begin{array}{l}\text { Source } \\
\text { area }\left(\mathrm{m}^{3}\right)\end{array}$ & $\begin{array}{l}\text { Flow } \\
\text { area }\left(\mathrm{m}^{3}\right)\end{array}$ & $\begin{array}{r}\text { Deposited } \\
\text { area }\left(\mathrm{m}^{3}\right)\end{array}$ \\
\hline Tungmen & 105,075 & 31,387 & 73,687 \\
Hoser & 490,350 & 48,020 & 442,330 \\
Chonho & 68,890 & 53,410 & 37,320 \\
\hline
\end{tabular}

$1020 \mathrm{~m}$, to the deposited area, elevation $820 \mathrm{~m}$. Accumulated geomaterial from the source area totalled around $490,350 \mathrm{~m}^{3}$. A total of $48,020 \mathrm{~m}^{3}$ were distributed on the flow area of the gully, while another $442,330 \mathrm{~m}^{3}$ had settled on the deposition area (Fig. 5). In the Chonho area, 71 profiles were used to compare their morphologic changes from the source area, elevation $450 \mathrm{~m}$, to the deposition area, elevation $50 \mathrm{~m}$. Accumulated geomaterial from the source area totalled around $68,890 \mathrm{~m}^{3}$. A total of $53,410 \mathrm{~m}^{3}$ was deposited on the flow area, while nearly $37,320 \mathrm{~m}^{3}$ had flowed to the exit of the gully. The great volume changes in the gullies can be identified for the different periods in the study areas.

Several differences in morphologic changes were analyzed by comparing profiles from different years before and after the debris flow. Finally, the dumped material was identified as the principal sliding material responsible for these hazardous debris flows.

\section{Discontinuity distribution}

The geological structure of the three disaster areas contains a number of discontinuities across a broad region. The rock types of Tungmen area belong to the Paleozoic Tananao schist formation (Chen and Yang, 1985). They consist mainly of quartz-mica schist, phyllite, mica schist 

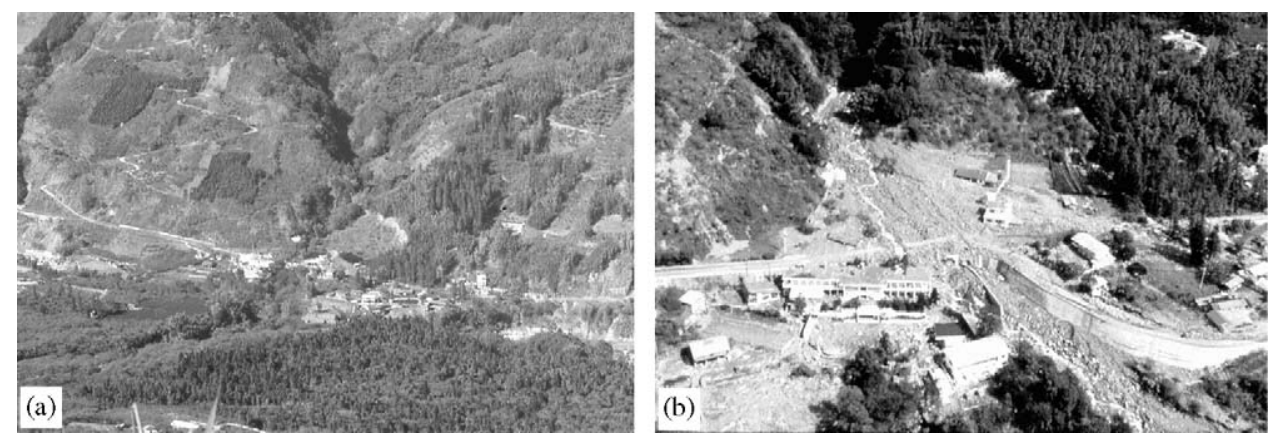

Fig. 5. Comparisons of the top view before (a) and after the disaster (b) when Typhoon Herb passed through the Hoser area.

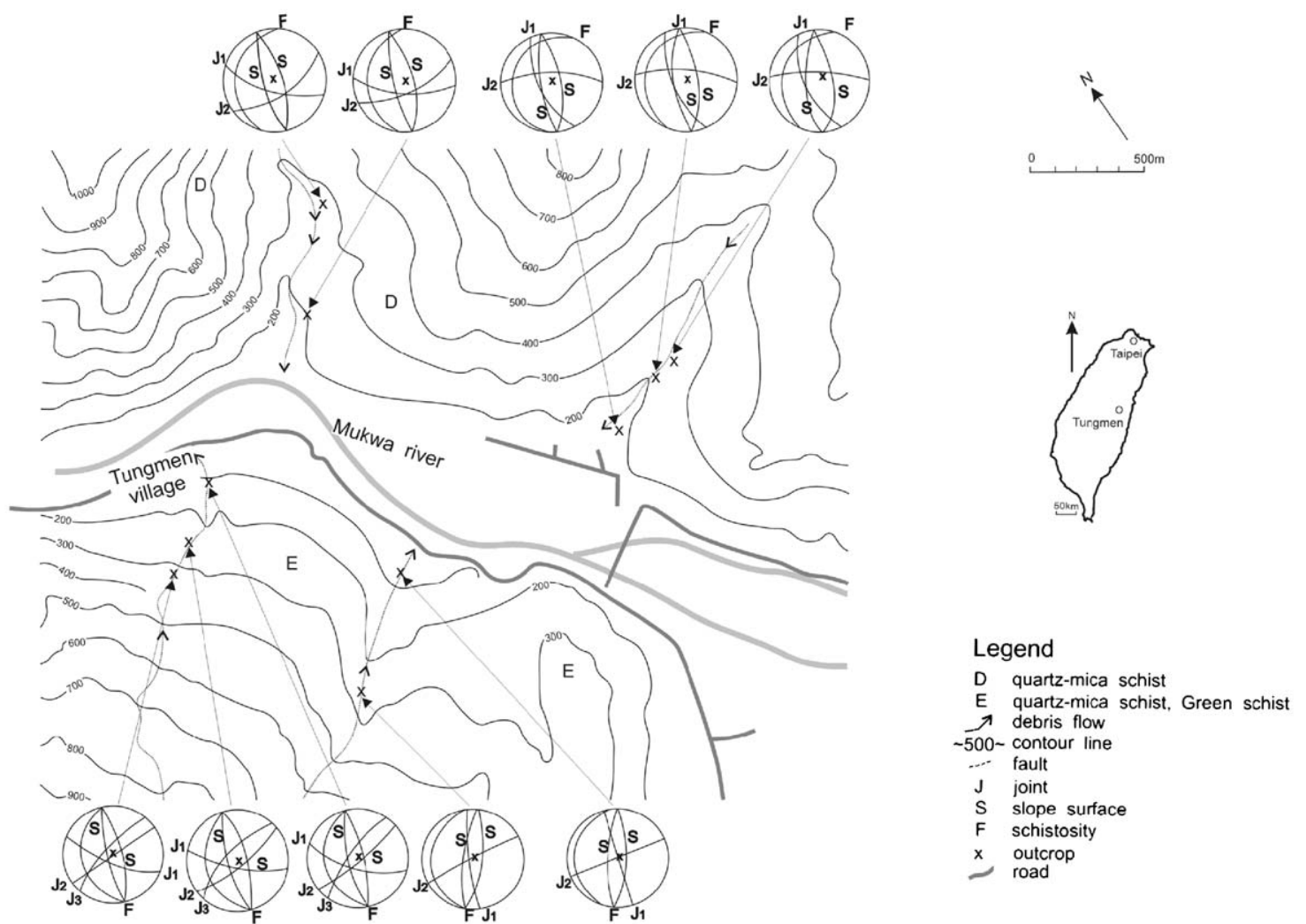

Fig. 6. Stereonet projections showing the various geometric failure models in the Tungmen area.

and mica quartzite. The attitude of schistosity is $\mathrm{N} 40^{\circ} \mathrm{E}$ and the dip is $11^{\circ}$ westward in the study area. There is a $2 \mathrm{~mm}$ to $4 \mathrm{~cm}$ spacing distributed on the schistosity. The attitudes of the three joints are: (1) $\mathrm{N} 80^{\circ} \mathrm{W}$, with a northerly dip of $74^{\circ}$, (2) $\mathrm{N} 10^{\circ} \mathrm{W}$, with a southerly dip of $78^{\circ}$, and (3) $\mathrm{N} 67^{\circ} \mathrm{W}$, with a southerly dip of $88^{\circ}$ (Fig. 6).

The rock types of the Hoser area consist of massive shale, sandy shale and fine interbeds of sandstone and shale. They belong to the Hoser Formation of Miocene age (Ho, 1986). Different sets of discontinuities have intervals varying from $10 \mathrm{~cm}$ to $1 \mathrm{~m}$. The strike of bedding is $\mathrm{N} 40^{\circ} \mathrm{E}$ and the dip is $60^{\circ}$ towards the northwest. The three sets of joints are (1) $\mathrm{N} 30^{\circ} \mathrm{E}$, with a southerly dip of $85^{\circ}$, (2)
$\mathrm{N} 35^{\circ} \mathrm{W}$, with a northerly dip of $40^{\circ}$, and (3) $\mathrm{N} 70^{\circ} \mathrm{W}$, with a southerly dip of $50^{\circ}$ (Fig. 7). Calcite and quartz most commonly fill the discontinuities.

The rock types of the Chonho area on the upper stream belong to the Tatun volcanic series of the early Pleistocene (Chen, 1975). It consists mainly of lava flow and pyroclastic material. Andesite and tuff form the major composition of the study area. The average attitudes in the two sets of joints are: (1) $\mathrm{N} 65^{\circ} \mathrm{W}$, with a southerly dip of $80^{\circ}$, and (2) $\mathrm{N} 80^{\circ} \mathrm{W}$, with a northerly dip of $75^{\circ}$. The downstream of the Chonho area consists of muddy sandstone of the Nanchuang Formation of the Miocene age. The attitude of bedding is $\mathrm{N} 40^{\circ} \mathrm{E}$, with a northerly 
dip of $50^{\circ}$. Two sets of joints are: (1) $\mathrm{N} 85^{\circ} \mathrm{E}$ with a southerly dip of $60^{\circ}$, and (2) $\mathrm{N} 10^{\circ} \mathrm{E}$, with a northerly dip of $63^{\circ}$ (Fig. 8).
These maps display the diversity of discontinuities distributed on the slopes along the gully sidewalls of the study areas. The data sets of discontinuities and slope

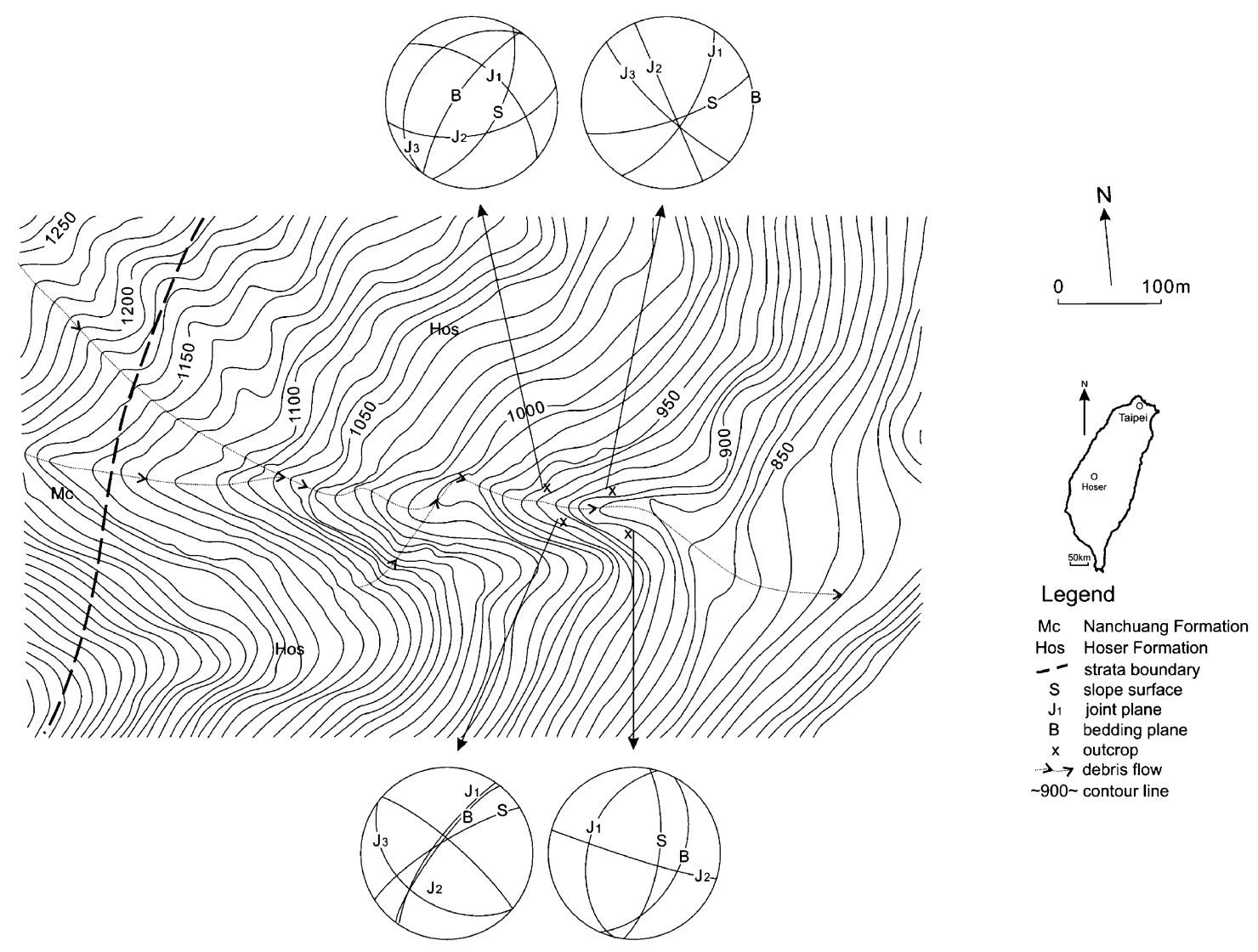

Fig. 7. Stereonet projection combined with joint and bedding planes in the Hoser area.

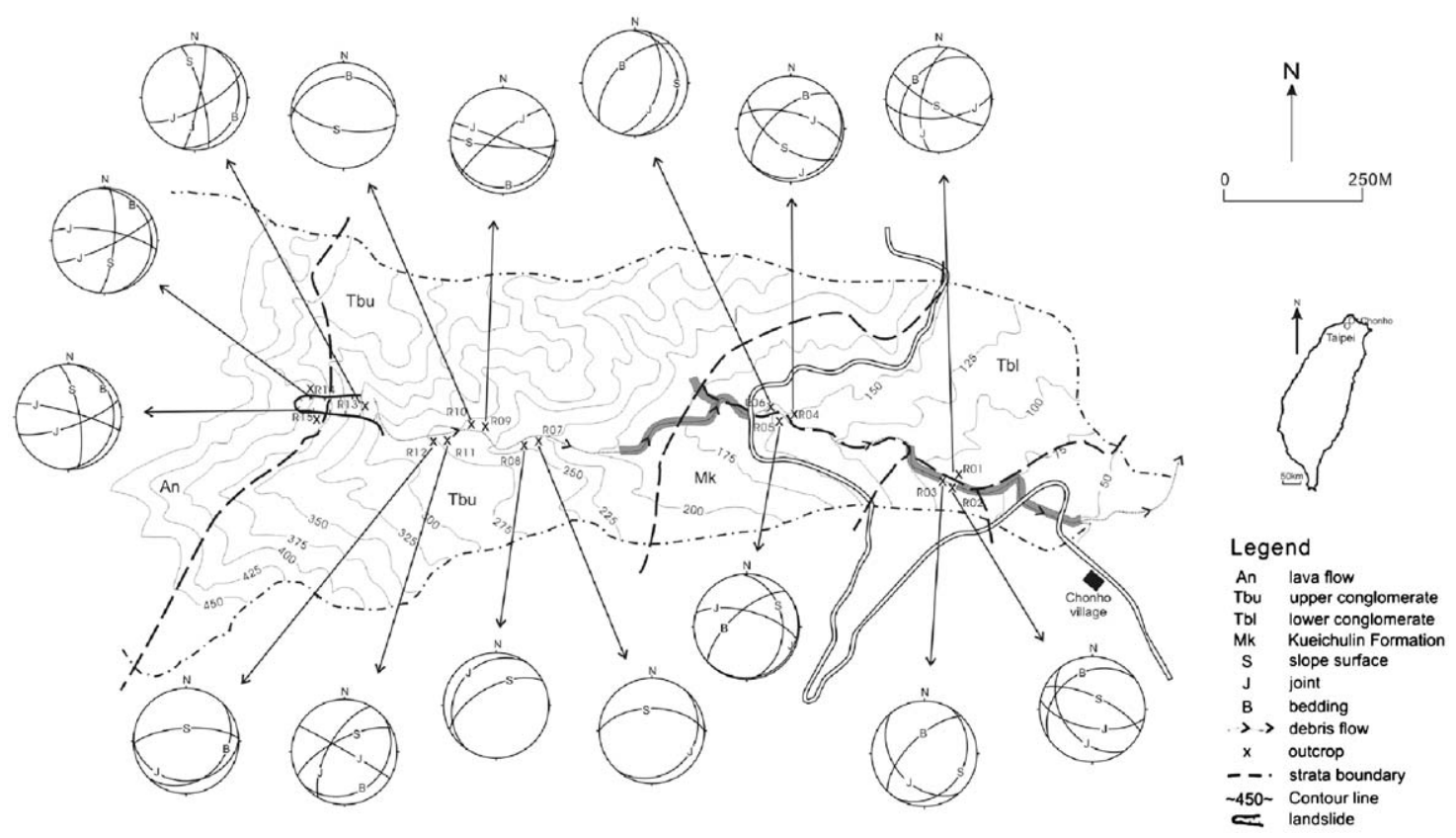

Fig. 8. Distribution of stereonet projections in the pyroclastic material in the Chonho area. 
surfaces were combined in various geometric models and introduced various possible failure types. These geometric types clearly indicate potential instabilities on the slope.

\section{Geomaterial characteristics}

The physical properties of the three study areas are summarized in Table 3. These figures reveal the major characteristics in the various rock types. This study selected direct shear data using the multistage method in order to determine the shear strengths of geomaterials from the various discontinuities on the lateral sidewalls of the exposed gully. These experimental tests on discontinuities included the rock material on bedding, schistosity and joint of the study areas (Table 4). Discontinuities on the exposed gully sides formed a potential failure model.

In the Tungmen area, the shear strength in the contact plane of schistosity was found to be $42^{\circ}$ under dry conditions and $27-35^{\circ}$ under saturated conditions for two sets of joints located on the exposed gully sides. Discontinuities on the exposed gully sides formed the potential plane and wedge models. One of the joints had a $40^{\circ}$ frictional angle under dry conditions, and $36^{\circ}$ under saturated conditions. The other one was $49^{\circ}$ under dry conditions, and $35-37^{\circ}$ under saturated conditions. In the Hoser area, the shear strength of the discontinuities plane in sandstone was $29-41^{\circ}$ under dry conditions, and $25-33^{\circ}$ in the saturated state. In the Chonho area, the shear strength in lava flow ranged from $34^{\circ}$ to $49^{\circ}$ under dry conditions, while the cohesion was $0.2 \mathrm{~kg} / \mathrm{cm}^{2}$. In a saturated state, the frictional angle would range from $23^{\circ}$ to $38^{\circ}$, and the cohesion angle from 0.2 to $0.4 \mathrm{~kg} / \mathrm{cm}^{2}$. These results were chosen for analyzing slope stability on both sidewalls of the exposed gullies in the study areas.

\section{Rainfall}

Three typhoons brought heavy rainfall and created hazardous debris flow in various rock type areas. Packing winds of up to $90 \mathrm{kt}$, Typhoon Ofelia tracked from the southeast to the northwest of Taiwan from 22 to 23 June 1990. This violent storm started unleashing heavy rainfall on the Tungmen area at $02: 00 \mathrm{pm}$ of 22 June which totalled $150 \mathrm{~mm}$ by 07:00am on 23 June (Fig. 9). The rainfall restarted at 08:00am and stopped at 04:00pm on 23 June, finally totalling $450 \mathrm{~mm}$ of rain. The debris flow began to appear on the afternoon of 23 June.

In late July 1996, Typhoon Herb brought heavy precipitation across Taiwan, from east to west. Rain began to fall in the Hoser area at 01:00am on $31 \mathrm{July}$, and by midnight the total precipitation had risen to $1100 \mathrm{~mm}$ - at which point the hazardous debris flow was triggered (Fig. 10). Over a $12 \mathrm{~h}$ period, from 06:00pm, 31 July, until 06:00am, 1 August, over $80 \mathrm{~mm} / \mathrm{h}$ of rainfall poured down, reaching a total accumulation of $1990 \mathrm{~mm}$ when the rain stopped at $04: 00 \mathrm{pm}$ on 1 August.

From 30 October to 1 November 2000, Typhoon Xangsane passed across Taiwan, from the southeast to the northeast. Heavy rain started falling in the Chonho area at 05:00am on 30 October, totalling $90 \mathrm{~mm}$ by 03:00am on 31 October - the first stage (Fig. 11). The rainfall resumed at 11:00am on 31 October and stopped at 02:00am on 2 November, adding $685 \mathrm{~mm}$. The debris flow began just before the midnight of 1 November.

A fierce rainstorm totalling around $250 \mathrm{~mm}$ in less than $10 \mathrm{~h}$ triggered debris flow once the precipitation flowed into a saturated zone of the slope. Such high intensity rainfall can infiltrate downward through the bed material to generate pore water pressure (Anderson and Sita, 1995; Dai et al., 1999). Thus, the landslide was triggered by an

Table 3

Physical properties of deposits in the gullies of the study areas

\begin{tabular}{|c|c|c|c|c|c|c|}
\hline Area & Sample No. & $\begin{array}{l}\text { Content of gravel } \\
(>2 \mathrm{~cm})(\%)\end{array}$ & Water content $(\%)$ & Unit weight $\left(\mathrm{t} / \mathrm{m}^{3}\right)$ & Void ratio $(\%)$ & $\begin{array}{l}\text { Degree of } \\
\text { saturation }(\%)\end{array}$ \\
\hline \multirow[t]{3}{*}{ Tungmen } & $\mathrm{T}-1$ & 74.8 & 3.7 & 1.86 & 0.53 & 19.2 \\
\hline & $\mathrm{T}-2$ & 83.4 & 2.5 & 1.74 & 0.62 & 11.0 \\
\hline & $\mathrm{T}-3$ & 49.6 & 6.5 & 2.15 & 0.33 & 52.9 \\
\hline \multirow[t]{6}{*}{ Hoser } & $P_{1}-1$ & 89.4 & 3.7 & 2.11 & 0.45 & 32.1 \\
\hline & $\mathrm{P}_{1}-2$ & 81.8 & 4.3 & 1.79 & 0.51 & 28.5 \\
\hline & $\mathrm{P}_{1}-3$ & 77.7 & 5.7 & 1.85 & 0.48 & 30.4 \\
\hline & $P_{3}-1$ & 78.5 & 4.6 & 1.94 & 0.46 & 29.7 \\
\hline & $\mathrm{P}_{3}-2$ & 72.7 & 3.8 & 2.05 & 0.41 & 28.1 \\
\hline & $\mathrm{P}_{3}-3$ & 75.1 & 3.4 & 1.83 & 0.43 & 25.4 \\
\hline \multirow[t]{6}{*}{ Chonho } & UP01 & 82.5 & 22.4 & 1.44 & 0.78 & 77.9 \\
\hline & UP02 & 86.7 & 22.0 & 1.38 & 0.77 & 78.7 \\
\hline & MP01 & 79.2 & 13.9 & 1.75 & 0.66 & 56.9 \\
\hline & MP03 & 86.7 & 10.4 & 1.81 & 0.61 & 46.3 \\
\hline & DP02 & 80.1 & 16.6 & 1.75 & 0.71 & 62.2 \\
\hline & DP03 & 88.4 & 18.8 & 1.78 & 0.76 & 67.0 \\
\hline
\end{tabular}


Table 4

Results of the shear strength of discontinuity in the three study areas

\begin{tabular}{|c|c|c|c|c|c|}
\hline Area & Discontinuity & Sample condition & Sample No. & Friction angle $\left({ }^{\circ}\right)$ & Remark \\
\hline \multirow[t]{9}{*}{ Tungmen } & \multirow[t]{4}{*}{ Schistosity plane } & Air dry & Tufd 1 & 42.0 & Schist \\
\hline & & \multirow[t]{3}{*}{ Saturated } & Tufw1 & 35.0 & \multirow[t]{3}{*}{ Schist } \\
\hline & & & Tufw2 & 36.5 & \\
\hline & & & Tuw3 & 31.0 & \\
\hline & \multirow[t]{5}{*}{ Joint plane } & \multirow[t]{2}{*}{ Air dry } & Tujd1-1 & 40.0 & \multirow[t]{2}{*}{ Schist } \\
\hline & & & Tujd2-1 & 49.0 & \\
\hline & & \multirow[t]{3}{*}{ Saturated } & Tujd1-1 & 36.0 & \multirow[t]{3}{*}{ Schist } \\
\hline & & & Tujd2-1 & 35.0 & \\
\hline & & & Tujd2-2 & 36.8 & \\
\hline \multirow[t]{12}{*}{ Hoser } & \multirow[t]{4}{*}{ Bedding plane } & \multirow[t]{2}{*}{ Air dry } & $12 \mathrm{Hbd}$ & 32.0 & Shale \\
\hline & & & $32 \mathrm{Hbd}$ & 29.0 & Shale \\
\hline & & \multirow[t]{2}{*}{ Saturated } & $12 \mathrm{Hbw}$ & 31.5 & Shale \\
\hline & & & $32 \mathrm{Hbw}$ & 24.0 & Shale \\
\hline & \multirow[t]{8}{*}{ Joint plane } & \multirow[t]{4}{*}{ Air dry } & $13 \mathrm{Hjd}$ & 39.0 & \multirow[t]{2}{*}{ Sandstone } \\
\hline & & & $14 \mathrm{Hjd}$ & 41.0 & \\
\hline & & & $32 \mathrm{Hjd}$ & 34.0 & \multirow[t]{2}{*}{ Sandstone } \\
\hline & & & $33 \mathrm{Hjd}$ & 38.0 & \\
\hline & & \multirow[t]{4}{*}{ Saturated } & $13 \mathrm{Hjw}$ & 33.0 & \multirow[t]{2}{*}{ Sandstone } \\
\hline & & & $14 \mathrm{Hjw}$ & 32.5 & \\
\hline & & & $32 \mathrm{Hjw}$ & 28.0 & \multirow[t]{2}{*}{ Sandstone } \\
\hline & & & $33 \mathrm{Hjw}$ & 34.0 & \\
\hline \multirow[t]{4}{*}{ Chonho } & \multirow[t]{4}{*}{ Joint plane } & Air dry & C14-1 & 48.2 & Andesite \\
\hline & & \multirow[t]{3}{*}{ Saturated } & $\mathrm{C} 14-2$ & 38.0 & \multirow[t]{3}{*}{ Andesite } \\
\hline & & & $\mathrm{C} 15-1$ & 23.2 & \\
\hline & & & $\mathrm{C} 15-2$ & 32.5 & \\
\hline
\end{tabular}

No intrinsic cohesion appeared in discontinuity.T: Tungmen, H: Hoser, C: Chonho, j: joint plane, f: schistosity plane, b: bedding plane, d: air dry, w: saturated.

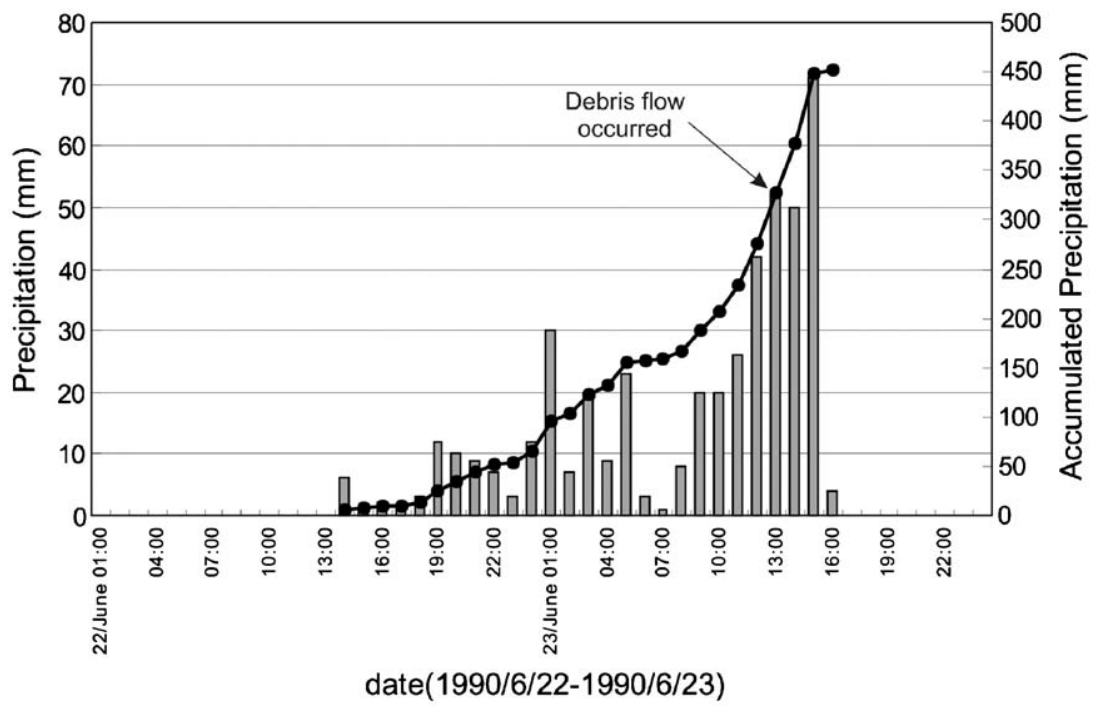

Fig. 9. Distribution of hourly and accumulated precipitation of Typhoon Ofelia in the Tungmen area.

extending failure in the source area, assembling the debris material into a flow state.

Pore water pressure will increase with increasing flow rate from heavy precipitation, especially when water is provided from the underneath of the gully substratum via discontinuities (Ala and Mathewson, 1990; Chen et al., 1999). Chen et al. (1999) used the laboratory tests to confirm the presence of increased pore water pressure by instrumentation. Coincident with the increased pore water pressure in the laboratory channel box study was rapid massive collapse of the material. The visual evidence of a cleanly flushed network of discontinuities exposed after the debris flow provided an in-situ indication of increased pore water pressure. 


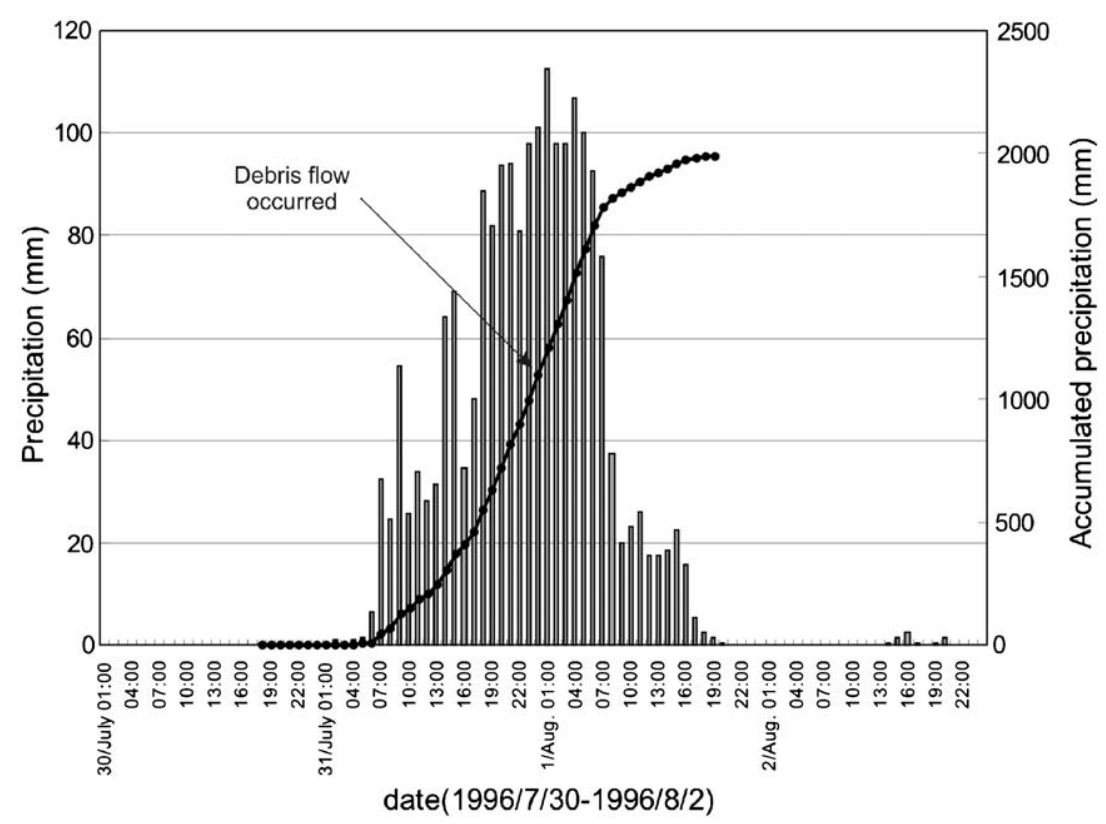

Fig. 10. Occurrence of debris flows when Typhoon Herb dropped a huge volume of precipitation on the Hoser area.

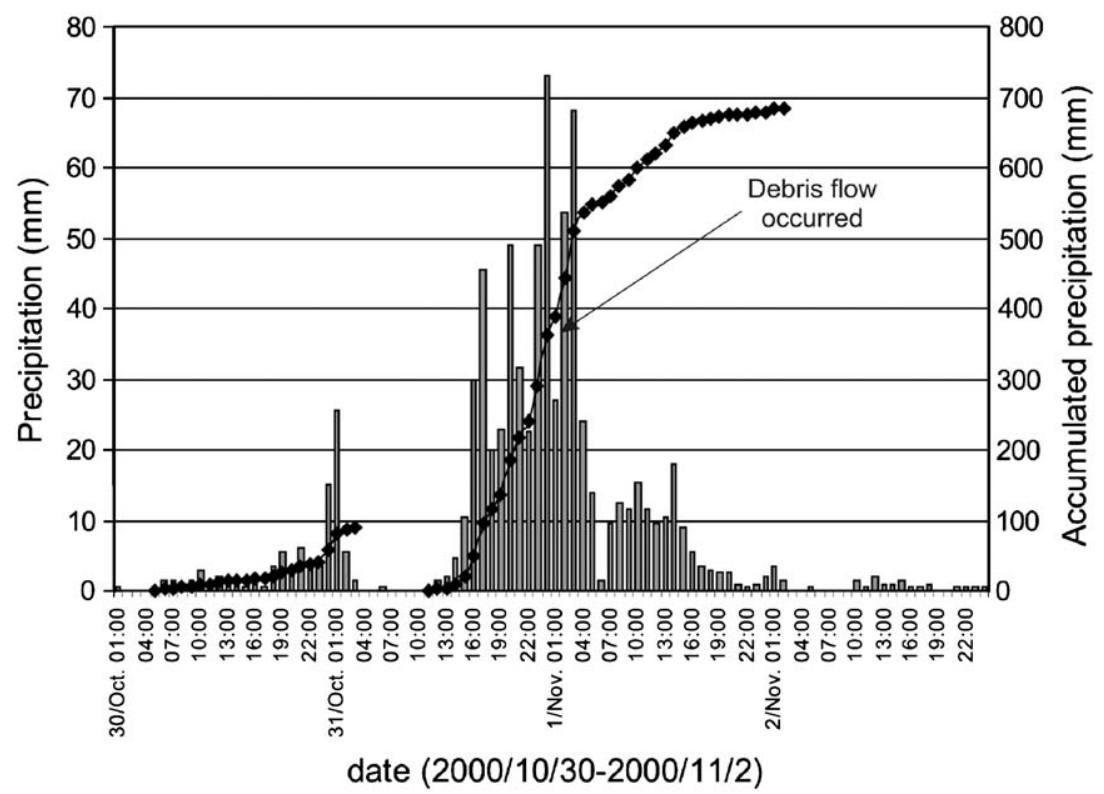

Fig. 11. Two stage distribution of hourly and accumulated precipitation of Typhoon Xangsane in the Chonho area.

In general, heavy precipitation could increase water content and water pressure, and decrease shear strength within the infiltrated stratum of the slope. These slopes lead to metastable accumulated material (Keefer et al., 1984; Chen et al., 1995). These phenomena would indicate that the rainfall dropping on the source area had reached a critical water pressure level acting on the dilative slip surface (Wieczorek et al., 2000; Chen and Su, 2001). Accordingly, the slope became unstable and triggered landslides.

The above results clearly show that the initial failure appeared at the source area. Initial movements of land- slides began with the runoff water that infiltrated into the slope surface of the study areas. The initial failure triggered a retrogressive sliding on both sidewalls of the erosion gully. Thus, movements accompanying an initial failure let the runoff water mix into the failed material, thus advancing the debris instability.

The rock bed of the erosion gully was shallow and fractured. However, this created more traces when the precipitation infiltrated the rock joints to the erosion gully. And this could go on fiercely for periods from hours to days - as during a major typhoon. 


\section{Stability condition of slope}

The quantitative analysis of slope stability was undertaken in order to comprehend the stable condition in the source area and on the lateral sidewalls of the gullies. These analytical methods include both discontinuities evaluation and safety factor computation. The outcrop attitudes of bedding, joint, schistosity and slope surface were measured by in-situ investigation, and plotted in a stereonet for discontinuities evaluation (Priest, 1992). Primary intersections of these discontinuities often form various geometric shapes, such as plane-failure, wedge-failure and topplefailure models. The results of the discontinuities projections also indicate the potentially unstable slopes of the study areas. The analytic approaches of various failure methods should be guided by specific information about the in-situ geological environment (Bromhead, 1986).

All potentially unstable models have quantified safety factors (Hoek and Bray, 1981). The plane-failure formula is as follows:

$F=\frac{c A+\left(W \cos \psi_{\rho}-U-V \sin \psi_{\rho}\right) \tan \phi}{W \sin \psi_{\rho}+V \cos \psi_{\rho}}$

where $c$ is the cohesion, $\mathrm{kN} / \mathrm{m}^{2}, \psi_{\rho}$ the dip angle of slip surface, degree, $A$ the length of slip surface, $\mathrm{m}, W$ the weight of failure mass, $\mathrm{t} / \mathrm{m}, U$ the uplift force, $\mathrm{t} / \mathrm{m}, V$ the lateral water pressure, $\mathrm{t} / \mathrm{m}, \phi$ the friction angle, degree.

The wedge-failure formula is

$F=\frac{\left(R_{\mathrm{a}}+R_{\mathrm{b}}\right) \tan \phi}{W \sin \varphi_{\mathrm{i}}}=\frac{\sin \beta \times \tan \phi}{\sin 1 / 2 \xi \times \tan \varphi_{\mathrm{i}}}$ where $R_{\mathrm{a}}, R_{\mathrm{b}}$ is the normal stress on mass $A$ and mass $B, \xi$ the intersected angle on mass $A$ and mass $B, \phi$ the friction angle, $\varphi_{\mathrm{i}}$ the dip angle of intersection line on two discontinuities, $\beta$ the tilt angle of wedge.

The basic equation for topple-failure is given as follows:

$F=\frac{\tan \phi_{j}}{\tan [\alpha-(90-\delta)]}$

where $\phi$ is the friction angle, $\alpha$ the dip angle of slope surface.

The safety factor of the outcrops on both sidewalls in the Tungmen, Hoser and Chonho areas indicates a potentially unstable state in saturated conditions (Table 5).

In the Tungmen area, the stability analysis of the plane failure model at Tuj-2D shows a safety factor of 1.13 and displays a stable state under normal dry conditions. When these slopes are saturated, a safety factor of 0.80 will descend below 1.0, and the slope will fail. Analysis of the wedge failure model at Tuf-1D, gives a safety factor of 1.03 under normal dry conditions. The safety factor descends to 0.89 when the ground water emerges to the slope surface.

In the Hoser area, some slopes on both sidewalls of $112 \mathrm{D}, 122 \mathrm{D}$ and $144 \mathrm{D}$ are in the stable state under normal dry conditions. Analyzing the plane failure model at the site of $112 \mathrm{~S}$, a safety factor of 0.97 reveals an unstable state under saturated conditions. The stability analysis of the wedge failure model at the sites of 133D and 144D found the derived safety factor to be 1.05 and 1.14 under normal dry conditions. The safety factor descends to 0.80 and 0.78 when the ground water emerges to the slope surface.

Table 5

Results of safety factor analysis on the outcrop of both sidewalls in the three study areas

\begin{tabular}{|c|c|c|c|c|c|}
\hline Study area & Site No. & $\theta\left(^{\circ}\right)$ & $\phi\left(^{\circ}\right)$ & $F$ & Failure model \\
\hline \multirow[t]{4}{*}{ Tungmen } & Tuf-1D & 54 & 42.0 & 1.03 & \multirow[t]{2}{*}{ Wedge failure } \\
\hline & Tu-1S & 54 & 40.0 & 0.89 & \\
\hline & Tuj-2D & 50 & 36.8 & 1.13 & \multirow[t]{2}{*}{ Plane failure } \\
\hline & Tuj-2S & 50 & 35.0 & 0.80 & \\
\hline \multirow[t]{8}{*}{ Hoser } & $112 \mathrm{D}$ & 48 & 32.0 & 1.11 & \multirow[t]{2}{*}{ Plane failure } \\
\hline & $112 \mathrm{~S}$ & 48 & 30.5 & 0.97 & \\
\hline & $122 \mathrm{D}$ & 46 & 32.0 & 1.64 & \multirow[t]{2}{*}{ Stable } \\
\hline & $122 \mathrm{~S}$ & 46 & 30.0 & 1.24 & \\
\hline & $133 \mathrm{D}$ & 61 & 39.0 & 1.05 & \multirow[t]{4}{*}{ Wedge failure } \\
\hline & $133 \mathrm{~S}$ & 61 & 33.0 & 0.80 & \\
\hline & 144D & 72 & 41.0 & 1.14 & \\
\hline & $144 S$ & 72 & 32.5 & 0.70 & \\
\hline \multirow[t]{10}{*}{ Chonho } & R11D & 65 & 40.0 & 1.20 & \multirow[t]{2}{*}{ Plane failure } \\
\hline & R11S & 65 & 31.5 & 0.95 & \\
\hline & R14D & 82 & 48.2 & 2.18 & \multirow[t]{4}{*}{ Wedge failure } \\
\hline & $\mathrm{R} 14 \mathrm{~S}$ & 82 & 37.0 & 1.47 & \\
\hline & $\mathrm{R} 15 \mathrm{D}$ & 80 & 34.2 & 1.15 & \\
\hline & $\mathrm{R} 15 \mathrm{~S}$ & 80 & 23.2 & 0.89 & \\
\hline & R04D & 64 & 34.5 & 1.17 & \multirow[t]{4}{*}{ Topple failure } \\
\hline & $\mathrm{R} 04 \mathrm{~S}$ & 64 & 32.0 & 0.94 & \\
\hline & R09S & 67 & 32.5 & 1.19 & \\
\hline & R09S & 67 & 30.0 & 0.98 & \\
\hline
\end{tabular}

$D$ : dry condition, $S$ : saturated condition, $\theta$ : slope grade of gully, $\phi$ : friction angle, $F$ : safety factor. 
Consequently, when the slopes are saturated, these slopes will start to fail.

In the Chonho area, the stability analysis of the plane failure model at the site of R11D shows a safety factor of 1.20 and reveals a stable state under normal dry conditions. When these slopes are saturated, the safety factor will fall below 1.0, and the slope will fail. Analyzing the wedge failure model at the sites of R14D and R15D, the safety factor derived is 2.18 and 1.15 under normal dry conditions. The safety factor descends to 0.89 only at the site of R15S when the ground water emerges to the slope surface. Analysis of the topple failure model at the sites of R04D and R09D shows a safety factor of 1.17 and 1.19. The results reveal a stable state under normal dry conditions.

In summary, these results indicate good stability under normal dry conditions in the study areas. Hence, the whole slope remained in a stable state when the ground water level was deep underground. When these slopes are saturated, however, the safety factor falls far below 1.0 and the slope becomes unstable. Accordingly, there is a critical water pressure level on the developing slip surface, at which the slope becomes unstable.

\section{Triggering mechanism}

Heavy precipitation commonly increases water content and pore water pressure, and generates a great volume of various geomaterials from the source areas (Chen et al., 2004). Initial movement of debris flow certainly begins with the rapid appearance of surface runoff water (Fig. 12). These waters are a major providing source of the debris flow material in the study areas.

Rainstorms related to the triggering of landslides and debris flows are often illustrated or schematically in terms of precipitation intensity versus rainstorm duration (Aleotti, 2004). These results also show the critical conditions for debris flow initiation. The surface runoff or the groundwater along the catchments could provide water for integration into a beginning failure $(\mathrm{Wu}$ and
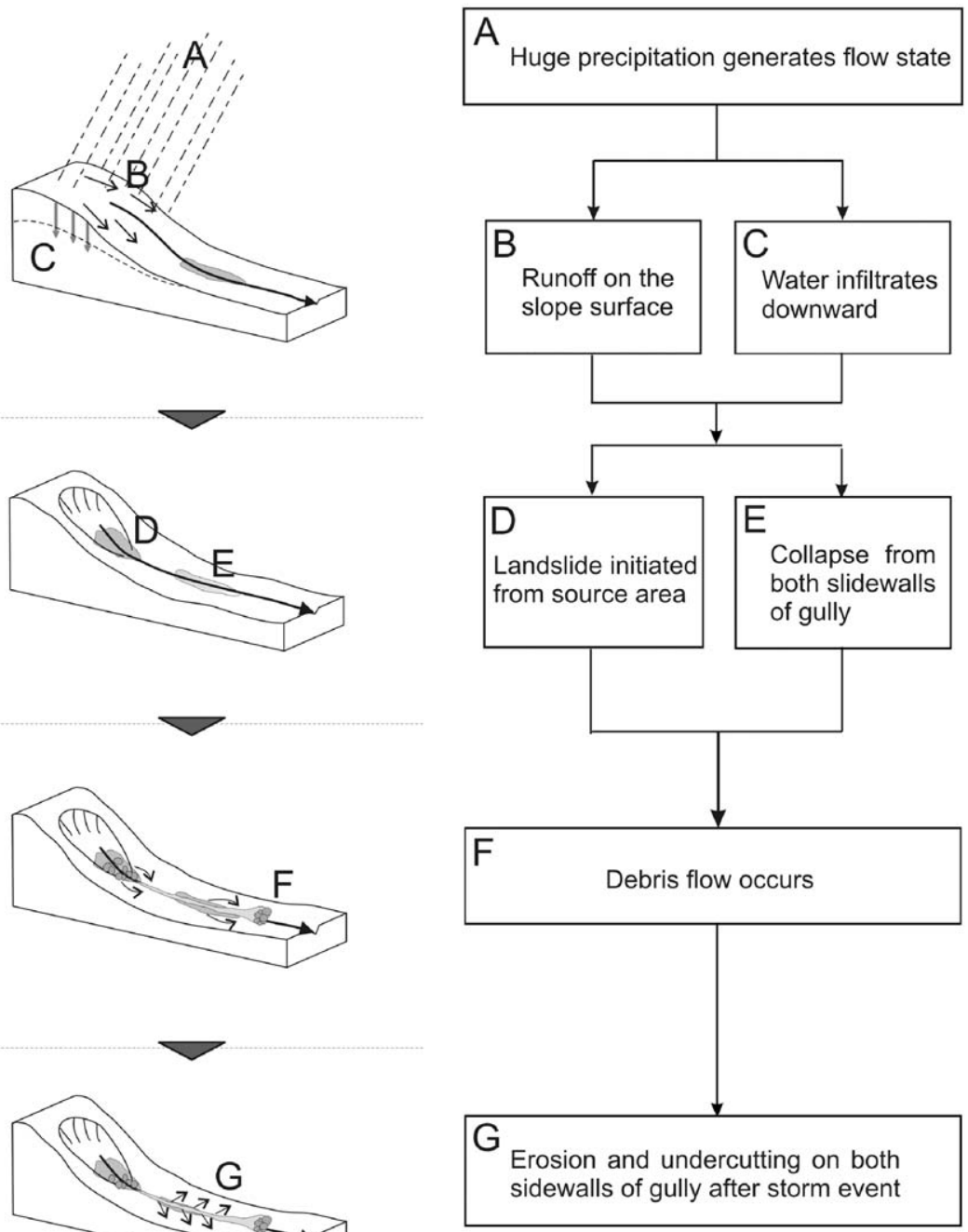

Fig. 12. Trigger mechanism of the debris flow occurrence in the three study areas. 
Swanston, 1980; Johnson and Sitar, 1990). The appearance of more water during subsequent intense precipitation is advantageous for mixing with accumulated material from the source area to stir the progression of a beginning landslide into a debris flow (Montgomery et al., 2000; Marchi et al., 2002).

Field investigation of the three case study areas revealed that the trigger mechanism of debris flow took place in two stages: the primary failure was due to slope movement with a gravitational and hydraulic action from the source area. In the gravitational action, debris movement was driven by the weight of its own accumulated materials. The hydraulic movement was transferred to the landslide mass of the source area flowing into brook track, following slope surface exposure to the action of running water.

Debris flows are commonly triggered by the sudden increase in pore water pressure on the material. This rapid increase in pore water pressure, however, may not always be attributable to the infiltration of precipitation (Wilson and Wieczorek, 1995). In the study areas, the debris flows resulted from the mixing of rock fragments, fine fractions and water, moving together down gullies with slope angles ranging from about $15-25^{\circ}$.

\section{Discussion}

A study of aerial photographs taken over 10- and 20year periods allowed a comparison of the terrain before and after three hazardous events. The aerial photographs revealed virtually no significant erosive changes in the area. This means that the gullies originally had not distributed a large volume of deposited material into the study area. Thus, this study examines the geometry of debris flow sources and provides a better understanding of these sources of gullies.

Experimental results demonstrated that precipitation increases the water content, thereby increasing the pore water pressure and decreasing the shear strength of the geomaterial (Sidle and Swanston, 1982). Consequently, these deposits become, in effect, "loaded cannons" waiting for precipitation to trigger debris flow and send a deluge rushing down the river bed, engulfing everything in its path. Historically, relatively few sources of debris flow would accumulate over relatively long time periods of 10-20 years, as verified by the aerial photographs.

\section{Conclusions}

Discontinuities in the sidewalls can be a major factor in providing massive amounts of debris flow material. These accumulated materials are eroded and undercut from gully sidewalls. The deposits above suddenly fall into the main flow and trigger enormous and potentially devastating debris flow driven by high intensity rainfall. The investigative results emphasize that sequential aerial photography was an essential tool for documenting the dramatic changes in topography over the studied time period necessary for understanding these events.

This comparative study of three cases has demonstrated that debris flows are often triggered and moved by high intensity rainfall, while the accumulated deposition is produced and supplied from both sidewalls of the affected gullies.

\section{Acknowledgments}

The author would like to thank the National Science Council, ROC, for generously supporting this research project financially. Thanks are also extended to Prof. K. Thompson of National Taiwan University for the paper revision and Ms. C.M. Yu for improving the figures. Two anonymous reviewers provided critical comments which are grateful appreciated.

\section{References}

Ala, S., Mathewson, C.C., 1990. Structural control of ground-water induced debris flow. Hydraulics/Hydrology of Arid Lands, 590-595.

Aleotti, P., 2004. A warning system for rainfall-induced shallow failures. Engineering Geology 73, 247-265.

Anderson, S.A., Sita, N., 1995. Analysis of rainfall-induced debris flows. Journal of Geotechnical Engineering 121, 544-552.

Baldwin II, J.E., Donley, H.F., Howard, T.R., 1987. On debris flow/ avalanche mitigation and control, San Francisco Bay area, California. Geological Society America, Reviews in Engineering Geology II, 223-236.

Bromhead, E.N., 1986. The Stability of Slope. Surrey University Press, New York 373pp.

Chen, C.H., 1975. Petrological and chemical study of volcanic rock from Tatun volcano group. Proceeding of Geological Society China 18, 59-72.

Chen, H., 2000. The geomorphological comparison of two debris flows and their triggering mechanisms. Bulletin of Engineering Geology and the Environment 58 (4), 297-308.

Chen, H., Su, D.Y., 2001. Geological factors for hazardous debris flows in Hoser, central Taiwan. Environmental Geology 40, 1114-1124.

Chen, H., Chen, R.H., Lin, M.L., 1999. Initiation of the Tungmen Debris Flow, Eastern Taiwan. Environmental \& Engineering Geoscience V (4), 459-473.

Chen, H., Chen, R.H., Yu, F.C., Chen, W.S., Huang, J.J., 2004. The inspection of the triggering mechanism for a hazardous mudflow in an urbanized territory. Environmental Geology 45, 899-906.

Chen, R.H., Lin, M.L., Chen, H., 1995. Mechanism of initiation of debris flow. In: Cheng, F.Y., Shew, M.S. (Eds.), Urban Disaster Mitigation. Elsevier Science, Oxford, pp. 231-243.

Chen, W.H., Yang, C.N., 1985. Structure of the Tananao Schist in the Tungmen area, Hualien, Taiwan. Ti-Chih 6 (2), 1-20.

Dai, F., Lee, C.F., Wang, S., 1999. Analysis of rainstorm-induced slidedebris flows on natural terrain of Lantau Island, Hong Kong. Engineering Geology 51, 279-290.

Ho, C.S., 1986. An Introduction to the Geology of Taiwan: Explanatory of the Geologic Map of Taiwan. The Ministry of Economic Affairs, Republic of China 153pp.

Hoek, E., Bray, J., 1981. Rock Slope Engineering. The Institution of Mining and Metallurgy, London, pp. 150-198.

Johnson, K.A., Sitar, N., 1990. Hydrologic conditions leading to debrisflow initiation. Canadian Geotechnical Journal 27, 789-801.

Keefer, D.K., Wilson, R.C., Mark, R.K., Brabb, E.E., Brown III, W.M., Ellen, S.D., Harp, E.L., Wieczorek, G.F., Alger, C.S., Zatkin, R.S., 
1984. Real-time landslide warning during heavy rainfall. Science 238, 921-925.

Marchi, L., Arattano, M., Deganutti, A.M., 2002. Ten years of debris-flow monitoring in the Moscardo Torrent (Italian Alps). Geomorphology $46,1-17$.

Montgomery, D.R., Schmidt, K.M., Greenberg, H.M., Dietrich, W.E., 2000. Forest clearing and regional landsliding. Geology 28 (4), 311-314.

Priest, S.D., 1992. Discontinuity Analysis for Rock Engineering. Chapman \& Hall, London 420pp.

Rib, H.T., Liang, T., 1978. Recognition and identification, In: Schuster, R.L., Krizek, R.J. (Eds.), Landslides Analysis and Control. Special report 176, pp. 34-80.

Shlemon, R.J., Wright, R.H., Montgomery, D.R., 1987. Anatomy of a debris flow, Pacifica, California. Geological Society of America, Reviews in Engineering Geology VII, 181-199.
Sidle, R.C., Swanston, D.N., 1982. Analysis of a small debris flow in coastal Alaska. Canadian Geotechnical Journal 19, 167-174.

Takahashi, T., 1991. Debris Flow: International Association Hydraulic Research. Balkema, 165pp.

VanDine, D.F., 1985. Debris flow and debris torrents in the Southern Canadian Cordillera. Canadian Geotechnical Journal 22, 44-62.

Wieczorek, G.F., Morgan, B.A., Campbell, R.H., 2000. Debris-flow hazard in the Blue Ridge of Central Virginia. Environmental \& Engineering Geoscience 6 (1), 3-23.

Wilson, R.C., Wieczorek, G.F., 1995. Rainfall thresholds for the initiation of debris flow at La Honda, California. Environmental \& Engineering Geoscience I (1), 11-27.

Wu, T.H., Swanston, D.N., 1980. Risk of landslides in shallow soils and its relation to cutting in southeastern Alaska. Forest Science 26 (3), 495-510. 